\title{
Analysis of marine combustion engine processes with vibroacoustic methods for environment protection strategy
}

\begin{abstract}
The paper describes the method of a sea boats online diagnostic with the use of the main and accompanying processes analyses. The paper concerns injection and combustion processes taking place in internal combustion engines of the military boats. Authors chosen vibroacoustic processes in the research to obtain the important diagnostic information on the above processes runs and their correctness in the sources of a drive of the HDV off-road water transport vehicles. The specified method of a digital data acquisition for dynamic processes in such combustion engines and sort of diagnostic parameters taken into account were basis of the required empirical research process and further signal analyses. High accuracy of the measurement methodology and process with additional conditions caused the authors could take the obtained signals to the parallel, combustion engineering and vibroacoustic engineering process, according to which they extract important information on the combustion processes runs and their problems. Identification of such problems and its type was helpful to build algorithm of the diagnostic assessment of such processes in the point of view of building diagnostic system for such military boats with the regime of the efficiency of the energy changes and emission control in the all exploitation period.
\end{abstract}

Key words: vibroacoustic diagnostics, injection and combustion processes, HD-D marine engine, digital signal analysis, emission assessment and control

\section{Analiza procesów zachodzących w spalinowych silnikach okrętowych za pomocą metod wibroakustycznych dla strategii ochrony środowiska naturalnego}

W artykule przedstawiono metodę ciagłej diagnostyki jednostek pływajacych z zastosowaniem analiz procesów głównych i towarzyszacych. Praca dotyczy procesów wtrysku i spalania paliwa w silniku spalinowym rozważanych dla jednostek ptywajacych. Wramach pracy badawczej wykorzystano procesy wibroakustyczne, celem uzyskania istotnych diagnostycznie informacji o poprawności przebiegu tychże procesów w napędach środków transportu wodnego kwalifikowanych do grupy HDV o zastosowaniach pozadrogowych. Podstawa wymaganego procesu badań empirycznych i nastęujacych po nim analiz sygnatów była zastosowana ściśle określona dla procesów dynamicznych metoda cyfrowej akwizycji danych oraz rodzaj uwzględnionych w analizie parametrów diagnostycznych. Duża doktadność metodyki pomiarowej i procesu wraz z uwzględnieniem warunków uzupetniajacych umożliwity dokonanie oceny uzyskanych sygnałów w ramach analizy inżynierskiej procesu spalania i oceny wibroakustycznej, zgodnie z którymi wybrano ważne informacje o przebiegu procesów spalania i nieprawidłowościach $w$ nich występujacych. Identyfikacja tychże nieprawidłowości $i$ wskazanie ich rodzaju stanowiło bazę do opracowania algorytmu oceny diagnostycznej powyższych procesów, z punktu widzenia budowy systemu diagnostycznego dla zastosowań okrętowych przy uwzględnieniu zmian sprawności energetycznej w obiekcie i kontroli emisji w calym okresie eksploatacji obiektu technicznego.

Słowa kluczowe: diagnostyka wibroakustyczna, procesy wtrysku i spalania paliwa, okrętowy silnik typu HD-D, analiza cyfrowa sygnatu, ocena i kontrola emisji

\section{Problem of toxic compounds emission from combustion engines of water means of transport}

The basic coefficient of the engine toxic emission is a specific emission of the toxic compound $\mathrm{e}_{\mathrm{zT}}[\mathrm{g} /(\mathrm{kW} \cdot \mathrm{h})]$. For the known run of the specific emission of the screw propeller characteristic $e_{\mathrm{ZT}}=f(n)$, an emission stream for a toxic compound is influenced by a power value which corresponds with specific torque of the propeller system, for a specific engine speed, according to an equation $[1-3,6]$ :

$$
\mathrm{E}_{\mathrm{ZTi}}=\mathrm{e}_{\mathrm{ZTi}} \cdot \mathrm{P}_{\mathrm{ei}}[\mathrm{g} / \mathrm{h}]
$$

where: $\mathrm{e}_{\mathrm{ZTi}}=\mathrm{f}\left(\mathrm{n}, \mathrm{W}_{\mathrm{Zi}}=\right.$ const $)$ - specific emission of $\mathrm{Z}_{\mathrm{T}}$ toxic

\section{Problem emisji składników toksycznych z silników spalinowych środków transportu wodnego}

Podstawowym wskaźnikiem emisji zanieczyszczeń zawartych w spalinach emitowanych przez silnik do atmosfery jest emisja jednostkowa związku toksycznego spalin $\mathrm{e}_{\mathrm{ZT}}$ $[\mathrm{g} /(\mathrm{kW} \cdot \mathrm{h})]$. Przy znanej charakterystyce śrubowej emisji jednostkowej związku toksycznego $e_{z T}=f(n)$ o wartości natężenia emisji i-tego związku do atmosfery decyduje wartość mocy odpowiadająca aktualnemu obciążeniu układu napędowego, przy określonej prędkości obrotowej, zgodnie z zależnością $[1-3,6]$ - wzór (1):

gdzie: $\mathrm{e}_{\mathrm{ZTi}}=\mathrm{f}\left(\mathrm{n}, \mathrm{W}_{\mathrm{Zi}}=\right.$ const $)$ - emisja jednostkowa związku 
compound; $\mathrm{P}_{\mathrm{ei}}=\mathrm{f}\left(\mathrm{n}, \mathrm{WZ}_{\mathrm{i}}=\right.$ const $)$ - engine power; $\mathrm{n}$ - engine velocity; $\mathrm{WZ}$ - outside conditions.

Description of internal combustion engines charging process is the most important task for assessment of toxic characteristics. Comparing engines of surface traction vehicles, aviations means of transport and other sources of a drive used in special systems, operation conditions for engines used in ships main propeller systems are specific, being shaped by resistance characteristics of boat unit and characteristics of shipborne propellers. At present (and probably in the nearest future of the sea-borne transport development) such conditions corresponds with generally used ship units with displacement ship hull and classical solutions of the screw propellers with constant pitch.

Engine work conditions and its toxic compounds emission are mostly created by so-called outside conditions, among which (because of important influence of line resistance of a hull) one can point at floating in restricted water regions (limited water depth and in waterways), floating in a storm, changes of a ship hull draught (e.g. because of loading increase, changes in tank and loading spaces ballasts) or water density changes, geometrical changes of outside parts and ship hull roughness as a result of its corrosion. Real conditions and processes of ships operation, regardless of given settings of power transmission system, can be both static and dynamic, according to processes runs of parameters in this system, and consequently both power and emission from main drive engines. Changes of the ship unit route (start, acceleration, deceleration) have also the influence on engine work conditions and its toxic compounds emission. Characteristics of such emission, as a functional relations describing phenomena that corresponds with charging of a ship main transmission system, are of the empirical nature. Emission tests created on the basis of empirical research performed in the real operation conditions are considered in the commonly used methods of the emission characteristics for internal combustion engines. Accuracy of emission evaluation depends on accuracy of the emission tests representation in relation to real operation conditions of engines described with engine speed and load. According to the ISO 8178 regulation for main drive ships engines, the present tests of such type are based on theoretical power screw characteristics $\mathrm{P}_{\mathrm{e}}=\mathrm{a} \cdot \mathrm{n}^{3}$ and are helpful in specific toxic compounds emission evaluation during test bench research.

Toxic compounds emissions changes as a result of alterations came from outside work conditions of a ship movement system are caused by any case effective power variations taken by the changed ship hull resistance, what means that they can be evaluated on the basis:

- load ship hull characteristics with consideration of influence of the water depth on a hull resistance, additional resistances during storm from wind and wave, changes of the ship hull draught and its surface roughness;

- power characteristics as a function of a ship speed;

- full-load characteristics;

- screw propeller characteristics of power for main drive engines; toksycznego $(\mathrm{ZT}) ; \mathrm{P}_{\mathrm{ei}}=\mathrm{f}\left(\mathrm{n}, \mathrm{WZ}_{\mathrm{i}}=\right.$ const $)-$ moc silnika; $\mathrm{n}-$ prędkość obrotowa silnika; WZ - warunki zewnętrzne.

Najbardziej istotnym zadaniem z zakresu wyznaczania charakterystyk toksyczności silników spalinowych jest opis rzeczywistego procesu ich obciążeń. W porównaniu z silnikami stosowanymi w trakcji drogowej, powietrznej oraz w napędach innych urządzeń specjalnych, warunki użytkowania okrętowych silników napędu głównego są specyficzne, kształtowane przez charakterystyki oporowe jednostki pływającej i charakterystyki pędników okrętowych. Na obecnym etapie (i przypuszczalnie w najbliższym okresie rozwoju transportu morskiego) warunki te odpowiadają powszechnie użytkowanym jednostkom pływającym o kadłubach wypornościowych oraz klasycznym rozwiązaniom śrub napędowych o stałym skoku.

Warunki pracy silnika i jego emisji zanieczyszczeń w spalinach są w dużej mierze kształtowane także przez tak zwane warunki zewnętrzne, spośród których, ze względu na znaczący wpływ na opór kadłuba, należy wyróżnić pływanie na akwenach ograniczonych (o ograniczonej głębokości wody i w kanałach), pływanie w sztormie, zmiany zanurzenia kadłuba (np. w wyniku zwiększenia załadunku, zmian w balastowaniu zbiorników i przestrzeni ładunkowych czy zmian gęstości wody), zmiany rozmiarów części wystających oraz chropowatości kadłuba w następstwie jego porastania i korozji. Rzeczywiste warunki i procesy użytkowania jednostek pływających, niezależnie od zadanych nastaw sterowania układem napędowym, mogą być zarówno statyczne, jak i dynamiczne, ze względu na przebiegi procesów zmian parametrów układu napędowego oraz (w konsekwencji) mocy i związanej w tym emisji zanieczyszczeń z silników napędowych. Na warunki pracy silnika i emisję zanieczyszczeń mają wpływ również zadane przez załogę zmiany ruchu jednostki pływającej (ruszanie z miejsca, przyspieszanie, hamowanie).

Charakterystyki tej emisji, jako zależności funkcyjne opisujące zjawiska związane z obciążeniem okrętowego układu napędu głównego, mają charakter wyłącznie empiryczny. W powszechnie stosowanych metodach wyznaczania charakterystyk emisji związków toksycznych przez silniki spalinowe podstawę stanowią testy toksyczności wyznaczone na podstawie empirycznych badań w rzeczywistych warunkach ich użytkowania. Dokładność szacowania emisji zależy więc od dokładności odwzorowania stosowanymi testami rzeczywistych warunków użytkowania silników opisanych zwykle parametrami ich obciążenia. W odniesieniu do okrętowych silników głównych, zgodnie z normą ISO 8178 , istniejące tego typu testy opierają się na teoretycznej charakterystyce śrubowej $\mathrm{P}_{\mathrm{e}}=\mathrm{a} \cdot \mathrm{n}^{3}$ i służą do wyznaczenia emisji jednostkowej związków toksycznych podczas badań hamownianych.

Zmiany emisji związków toksycznych w następstwie zmiany zewnętrznych warunków pracy układu ruchowego okrętu są konsekwencją w każdym przypadku zmiany użytecznej mocy zapotrzebowanej przez zmieniony opór kadłuba, co oznacza, że mogą być określone w sposób przybliżony na podstawie: 
- parameters of a ship movement system in nominal and transient load conditions (during start, acceleration and deceleration of a ship - time $t$ and route $S$ ).

In the above case, the power is the best parameter describing load state of the main drive engines, that corresponds with speed of a ship unit in the specified outside conditions of its operation. Consequently, changes of outside floating conditions have the influence on work of a ship power transmission system, both of the dynamic and static nature.

Ship engines can work generally in three different, conventionally defined load conditions:

- design (standard) - corresponding to the use of a ship unit at normal values of a total resistance of a hull (hull surface roughness and the value of a ship unit loading are constant and correspond with design conditions, floating in the sea state to $3{ }^{\circ} \mathrm{B}$ on non-limited sea area);

- real, that are results of changed outside conditions;

- dynamic - change of parameters of ship unit transmission system is in a specified time, as a result of its steering and of outside conditions independent influence e.g. during parameter changes of ship unit being taken by operator (start, acceleration, speed changes, active deceleration) and during fast outside conditions changes (e.g. sea region depth, ship unit route direction).

The main characteristics describing work conditions of the engine at the ship transmission system results from a resistance characteristics of a ship unit and a screw-propeller. Both characteristics are built in the design process empirically during model testing. Degree of compatibility of such built characteristics depends on projection accuracy of a real object in a model and conditions of performed measurements and calculations. Above characteristics can be used in research of ship units engines for diagnostic and emission assessment, more the changes of elementary engine work parameters (torque and speed) influence on a structure and emission of toxic compounds of such engines.

The subject of the toxic compounds emission equation assessment for engines being a source of a drive of water means of transport are global emission processes, averaging at enough long time [2]. The above time is dependent on process of averaging of operation conditions variables. Among the main factors that determine global emission from ship engines are:

a) ship unit structure, engine size and type, number of engines on a ship unit, engines technical state and used technical solutions,

b) operation intensity of water means of transport,

c) movement model of such means of transport,

d) environmental conditions (atmosperic, weather conditions, water region, floating conditions),

e) economical properties considering operation fuel consumption,

f) ecological properties of water means of transport

g) fuels parameters and their preparation.

Application of ship unit, its size, type and number of engines, type of used transmission system and technical
- charakterystyki oporowej kadłuba z uwzględnieniem: wpływu głębokości drogi wodnej na opór kadłuba, dodatkowych oporów podczas sztormu od wiatru oraz fali, zmiany zanurzenia kadłuba i jego chropowatości;

- charakterystyki mocy w zależności od prędkości okrętu;

- charakterystyki obciążeniowej;

- charakterystyki śrubowej mocy silników napędu głównego;

- parametrów układu ruchowego w nominalnych oraz przejściowych warunkach obciążenia (podczas ruszania z miejsca, przyspieszania i hamowania okrętu - czasu t i drogi S).

W powyższym przypadku najwygodniejszymi parametrami charakteryzującymi stan obciążenia silników napędu głównego jest ich moc odpowiadająca prędkości jednostki pływającej w określonych warunkach zewnętrznych użytkowania. Zmiana zewnętrznych warunków pływania w konsekwencji ma wpływ na pracę układu napędowego, zarówno o charakterze dynamicznym, jak i statycznym.

Silniki okrętowe mogą pracować zasadniczo w trzech różnych umownie zdefiniowanych warunkach obciążeń:

- projektowych (standardowych) - odpowiadających wykorzystaniu jednostki pływającej przy normalnych wartościach oporu całkowitego kadłuba (chropowatość kadłuba oraz stan załadowania jednostki nie ulegają zmianie i odpowiadają warunkom projektowym, pływanie przy stanie morza do $3{ }^{\circ} \mathrm{B}$ na nieograniczonym akwenie morskim);

- rzeczywistych, które są następstwem zmienionych warunków zewnętrznych;

- dynamicznych - w określonym czasie następuje zmiana parametrów pracy układu napędowego w następstwie jego sterowania, jak i samoistnego oddziaływania warunków zewnętrznych, np. podczas zadanych przez operatora zmian parametrów ruchu jednostki pływającej (ruszania z miejsca, przyspieszania, zmian prędkości, hamowania aktywnego) i podczas nagłych zmian warunków zewnętrznych (np. głębokości akwenu pływania, kierunku ruchu jednostki).

Podstawowa charakterystyka opisująca warunki pracy silnika w okrętowym układzie napędowym wynika z charakterystyki oporowej jednostki pływającej oraz charakterystyki śruby napędowej. Obie charakterystyki wyznacza się w fazie projektowania doświadczalnie podczas badań modelowych. Stopień zgodności z rzeczywistością tak sporządzonej charakterystyki zależy więc od dokładności odwzorowania rzeczywistego obiektu w modelu oraz warunków realizowanych pomiarów i obliczeń. Powyższe charakterystyki mogą być stosowane w badaniach silników okrętowych w ramach oceny diagnostycznej i emisyjnej, tym bardziej iż zmiany składowych parametrów pracy silnika (momentu i prędkości obrotowej) wpływają w sposób istotny na strukturę oraz emisję związków toksycznych przez powyższe silniki.

Przedmiotem oceny bilansu emisji składników szkodliwych spalin w silnikach napędzających środki transportu wodnego są procesy emisji globalnej, uśrednione w dostatecznie długim czasie [4]. Powyższy czas jest zależny od 
level of a ship unit have also influence on a global emission of water means of transport.

\section{Emission norms for combustion engines of water means of transport}

Air pollution from ships causes a cumulative effect that contributes to the overall air quality problems encountered by populations in many areas, and also affects the natural environment, such as though acid rain. MARPOLAnnex VI, first adopted in 1997 by International Maritime Organization (IMO), limits two main air pollutants contained in ships exhaust gas: nitrous oxides $\left(\mathrm{NO}_{\mathrm{x}}\right)$ and sulphur oxides $\left(\mathrm{SO}_{\mathrm{x}}\right)$. It also prohibits deliberate emissions of ozone depleting substances, regulates shipboard incineration, and the emissions of volatile organic compounds from tankers [4].

Following entry into force of MARPOL Annex VI on 19 May 2005, Marine Environment Protection Committee (MEPC), at its $53^{\text {rd }}$ session in July 2005, agreed to revise MARPOL Annex VI with the main goal to significantly strengthen the emission limits in light of technological improvements and implementation experience. As a result of three years examination, MEPC 58 (October 2008) adopted the revised MARPOL Annex VI and the associated $\mathrm{NO}_{x}$ Technical Code 2008, which entered into force on 1 July 2010 [4].

The main changes to MARPOL Annex VI are a progressive reduction globally in emissions of $\mathrm{NO}_{x}, \mathrm{SO}_{\mathrm{x}}$ and particulate matter. As a new concept of environment protection was introduction of emission control areas (ECAs) to reduce emissions of those air pollutants further in designated sea areas. Progressive reductions in $\mathrm{NO}_{\mathrm{x}}$ emissions from marine diesel engines installed on ships are also included, with a "Tier II" emission limit for engines installed on or after 1 January 2011. Furthermore stringent is "Tier III" emission limit for engines installed on or after 1 January 2016 operating in ECAs. It is required that marine diesel engines installed on or after 1 January 1990 but prior to 1 January 2000 comply with "Tier I" emission limits, if an approved method for that engine has been certified by an Administration. The revised $\mathrm{NO}_{\mathrm{x}}$ Technical Code 2008 includes a new chapter based on the agreed approach for regulation of existing engines, which have been installed before 2000 , established in MARPOL Annex VI, provisions for a direct measurement and monitoring method, a certification procedure for existing engines, and test cycles to be applied to Tier II and Tier III engines [4-5, 7].

The $\mathrm{NO}_{\mathrm{x}}$ control requirements of Annex VI apply to installed marine diesel engine of over $130 \mathrm{~kW}$ output power, but other than those used solely for emergency purposes irrespective of the tonnage of the ship onto which such engines are installed. Different levels (Tiers) of control apply based on the ship construction date and within any particular Tier the actual limit value is determined from the engine's rated speed (Table 1, Fig. 1).

$\mathrm{SO}_{\mathrm{x}}$ and particulate matter emission controls apply to all fuel oil, combustion equipment and devices onboard and therefore include both main and all auxiliary engines procesu uśredniania zmiennych warunków eksploatacji. Do zasadniczych czynników determinujących emisję globalną z silników okrętowych należą:

a) struktura jednostek pływających, wielkość i rodzaj silnika, liczba poszczególnych silników na jednostce pływającej, stan techniczny silników oraz zastosowania rozwiązania techniczne,

b) intensywność eksploatacji środków transportu wodnego,

c) model ruchu powyższych środków transportu,

d) warunki otoczenia (atmosferyczne, akweny pływania, warunki pływania),

e) właściwości ekonomiczne uwzględniające eksploatacyjne zużycie paliwa,

f) właściwości ekologiczne środków transportu wodnego, g) właściwości paliw i ich przygotowanie.

$\mathrm{Na}$ emisję globalną z jednostek pływających ma ponadto wpływ przeznaczenie jednostki, jej wielkość, rodzaj i liczba silników, rodzaj zastosowanego układu napędowego oraz poziom techniczny jednostki pływającej.

\section{Normy emisji dla silników spalinowych wodnych środków transportu}

Emisja toksycznych składników spalin silników okrętowych powoduje występowanie skumulowanego efektu, który jest związany z ogólnym problemem jakości powietrza występujący w wielu dziedzinach życia, a także wpływa bezpośrednio na środowisko naturalne, np. przez występowanie kwaśnych deszczów. W 1997 roku Międzynarodowa Organizacja Morska (ang. International Maritime Organization - IMO) przyjęła założenia VI Aneksu do konwencji MARPOL, która ogranicza emisję dwóch podstawowych składników spalin silników okrętowych jakimi są tlenki azotu $\left(\mathrm{NO}_{\mathrm{x}}\right)$ i tlenki siarki $\left(\mathrm{SO}_{\mathrm{x}}\right)$. Konwencja ta zabrania również emisji substancji wpływających w niekorzystny sposób na warstwę ozonową, reguluje kwestie odpadów okrętowych i emisji lotnych składników organicznych ze zbiorników [4].

Po wejściu w życie założeń konwencji MARPOLAneks VI w dniu 19 maja 2005 roku, Komitet Ochrony Środowiska Morskiego (ang. Marine Environment Protection Committee - MEPC) na pięćdziesiątej trzeciej sesji w lipcu 2005 roku zgodził się na rewizję założeń Aneksu VI. Celem rewizji było zaostrzenie limitów emisji toksycznych składników spalin w świetle możliwości zastosowania nowych technologii i rozwiązań konstrukcyjnych. W wyniku trzyletnich badań, MEPC w październiku 2008 roku przyjął zmiany do Aneksu VI konwencji MARPOL i związany z nim NO Technical Code 2008, które weszły w życie 1 lipca 2010 roku [4].

Główne zmiany wprowadzone do Aneksu VI konwencji MARPOL stopniowa redukcja globalnej emisji $\mathrm{NO}_{x}, \mathrm{SO}_{x}$ i cząstek stałych. Jako nowa koncepcja ochrony środowiska zostały zaproponowane obszary kontrolowanej emisji (Emission Control Areas - ECAs), w obrębie których emisja wymienionych toksycznych składników spalin ma być jeszcze bardziej ograniczona. Stopniowa redukcja emisji $\mathrm{NO}_{x}$ przez silniki okrętowe zawarta jest także w normie „Tier II” 
together with items such boilers and inert gas generators. These controls are divided between two groups. First which is applicable inside Emission Control Areas (ECA) established to limit the emission of $\mathrm{SO}_{\mathrm{x}}$ and particulate matter and second which is applicable outside such areas and are primarily achieved by limiting the maximum sulphur content of the fuel oils as loaded, bunkered, and subsequently used onboard. These fuel oil sulphur limits (expressed in terms of $\% \mathrm{~m} / \mathrm{m}$ by weight) are subject to a series of step changes over the years (Table 2).

Table 1. Tier $\mathrm{NO}_{\mathrm{x}}$ emission regulations for water means of transport [4-5]

Tabela 1. Regulacje Tier dotyczace emisji $\mathrm{NO}_{x}$ środków transportu morskiego [4-5]

\begin{tabular}{|c|c|c|c|c|}
\hline Tier & $\begin{array}{c}\text { Ship pro- } \\
\text { duction date } \\
\text { on or after/ } \\
\text { data wejścia } \\
\text { jednostki do } \\
\text { stużby }\end{array}$ & \multicolumn{3}{|c|}{$\begin{array}{c}\text { Total weighted cycle emission limit }(\mathrm{g} / \mathrm{kWh}) \\
\mathrm{n}=\text { engine's rated speed }(\mathrm{rpm}) / \text { dopuszczalna } \\
\text { emisja jednostkowa }(\mathrm{g} / \mathrm{kWh})\end{array}$} \\
\cline { 3 - 6 } & $\mathrm{n}<130$ & $\mathrm{n}=130-1999$ & $\mathrm{n} \geq 2000$ \\
\hline I & 01.01 .2000 & 17.0 & $\begin{array}{c}45 \cdot \mathrm{n}^{-0.2} \\
\text { wego }(\text { obr/min) }\end{array}$ & 9.8 \\
\hline II & 01.01 .2011 & 14.4 & $\begin{array}{r}44 \cdot \mathrm{n}^{-0.23} \\
\text { e.g., } 720 \mathrm{rpm}-9.7\end{array}$ & 7.7 \\
\hline III & $01.01 .2016^{*}$ & 3.4 & $\begin{array}{r}9 \cdot \mathrm{n}^{-0.2} \\
\text { e.g., } 720 \mathrm{rpm}-2.4\end{array}$ & 2.0 \\
\hline
\end{tabular}

Table 2. Sulphur content Tier emission regulation changes dedicated to water means of transport for different ECA areas [4-5]

Tabela 2. Zmiany dopuszczalnej zawartość siarki w paliwie zgodnie z normami emisji Tier [4-5]

\begin{tabular}{|c|c|}
\hline $\begin{array}{l}\text { Outside an ECA established to } \\
\text { limit } \mathrm{SO}_{\mathrm{x}} \text { and particulate matter } \\
\text { emissions/poza obszarem ECA } \\
\begin{array}{l}\text { ustanowione celem ograniczenie } \\
\text { emisji } \mathrm{SO}_{x} \text { i czastek statych }\end{array}\end{array}$ & $\begin{array}{l}\text { Inside an ECA established to } \\
\text { limit } \mathrm{SO}_{\mathrm{x}} \text { and particulate matter } \\
\text { emissions/wewnatrz obszaru ECA } \\
\text { ustanowione celem ograniczenie } \\
\text { emisji } \text { SO }_{x} \text { i czastek statych }\end{array}$ \\
\hline $\begin{array}{c}4.50 \% \mathrm{~m} / \mathrm{m} \text { prior } \\
\text { to } 1 \mathrm{January} 2012\end{array}$ & $\begin{array}{c}1.50 \% \mathrm{~m} / \mathrm{m} \text { prior } \\
\text { to } 1 \mathrm{July} 2010\end{array}$ \\
\hline $\begin{array}{c}3.50 \% \mathrm{~m} / \mathrm{m} \text { on and after } \\
1 \mathrm{January} 2012\end{array}$ & $\begin{array}{c}1.00 \% \mathrm{~m} / \mathrm{m} \text { on and after } \\
1 \mathrm{July} 2010\end{array}$ \\
\hline $\begin{array}{c}0.50 \% \mathrm{~m} / \mathrm{m} \text { on and after } \\
1 \mathrm{January} 2020 *\end{array}$ & $\begin{array}{c}0.10 \% \mathrm{~m} / \mathrm{m} \text { on and after } \\
1 \mathrm{January} 2015\end{array}$ \\
\hline
\end{tabular}

Under the revised MARPOL Annex VI, the global sulphur cap is reduced to $3.50 \%$ from previous $4.50 \%$, effective from 1 January 2012. Then the sulphur can will be progressively reduced to final $0.50 \%$, effective from 1 January 2020, subject to a feasibility review to be completed no later than 2018. The $\mathrm{SO}_{\mathrm{x}}$ and particulate matter limits applicable in ECAs were reduced to $1.00 \%$ from the original $1.50 \%$ beginning on 1 July 2010 , and will be further reduced to $0.10 \%$, effective from 1 January 2015 (Fig. 2).

The established ECAs are:

1. Baltic Sea area - as defined in Annex I of MARPOL $\left(\mathrm{SO}_{\mathrm{x}}\right.$ only),

2. North Sea area - as defined in Annex V of MARPOL (SO only),

3. North American area as defined in Appendix VII of Annex VI of MARPOL $\left(\mathrm{SO}_{\mathrm{x}}, \mathrm{NO}_{\mathrm{x}}\right.$ and PM), dla silników instalowanych na statkach po 1 stycznia 2011 roku. Jeszcze bardziej restrykcyjna jest norma „Tier III" dla silników montowanych w maszynowniach okrętowych po 1 stycznia 2016 roku operujących w granicach ECAs. Dla silników zainstalowanych w okresie od 1.01.1990 do 1.01.2000 wymagane jest spełnienie poziomu emisji przewidzianego w normie ,,Tier I” jeśli przyjęta metoda dla danego silnika uzyskała administracyjną certyfikację. Zmieniona treść Technical Code 2008 zawiera nowy rozdział oparty na uzgodnieniach związanych z regulacjami dotyczącymi eksploatowanych silników zainstalowanych przed 1.01.2000 zwartymi w Aneksie VI konwencji MARPOL, postanowienia dla bezpośrednich pomiarów i metod monitorowania, procedurę certyfikacyjną dla istniejących silników oraz przebieg testu, który ma być wykorzystany do silników Tier II i Tier II $[4,5,7]$.

Wymagana kontroli emisji $\mathrm{NO}_{\mathrm{x}}$ zawarte w Aneksie VI odnoszą się do morskich silników o zapłonie samoczynnym o mocy maksymalnej powyżej $130 \mathrm{~kW}$, ale innych niż tych używanych w celach czysto awaryjnych, niezależnie od tonażu statku, w którego maszynowni dany silnik jest zainstalowany. Różne poziomy kontroli (Tiers) odnoszą się do danej jednostki pływającej w zależności od daty oddania jej do użytku. Natomiast w obrębie wybranej normy Tier wartość emisji jest zależna od maksymalnej prędkości obrotowej wału korbowego silnika, co zaprezentowano w tabeli 1 i na rys. 1 .

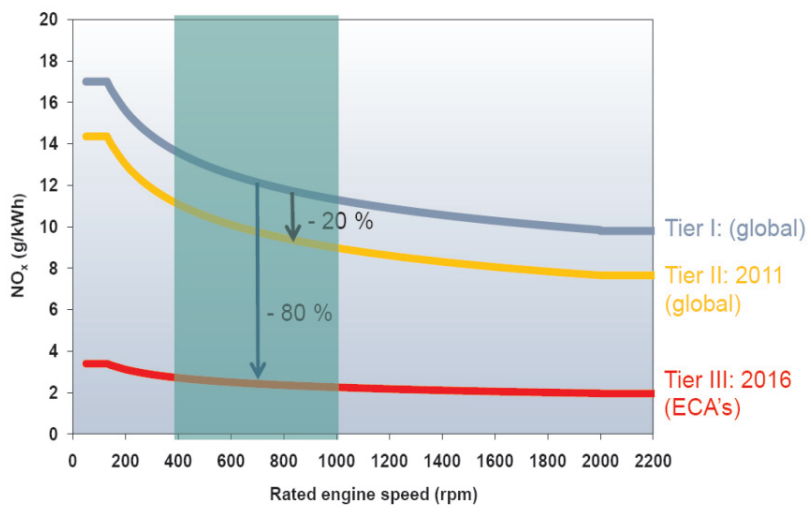

Fig. 1. $\mathrm{NO}_{\mathrm{x}}$ emission limits for Tier regulations and water means of transport [4-5]

Rys. 1. Limity emisji $\mathrm{NO}_{x}$ norm Tier dla środków transportu wodnego [4-5]

Kontrola emisji $\mathrm{SO}_{\mathrm{x}}$ i cząstek stałych odnosi się do wszystkich urządzeń na pokładzie statku, w których wykorzystywany jest proces spalania. Tym samym zarówno silniki napędu głównego jak i silniki pomocnicze, oraz urządzenia typu kotły parowe czy generatory gazów obojętnych są objęte limitami emisji. Kontrola ta jest podzielona na dwie grupy. Pierwsza grupa stosowana jest wewnątrz obszaru ECAs, druga natomiast poza obszarami ECAs. Obniżenie emisji tlenków siarki jest uzyskiwane głównie na drodze limitowania zawartości siarki w paliwie, która jest przedmiotem szeregu zmian w dłuższym okresie czasu (tabela 2). 
4. United States Caribbean Sea area, which is expected to enter into force 1 January 2014), as defined in Appendix VII of Annex VI of MARPOL $\left(\mathrm{SO}_{x}, \mathrm{NO}_{\mathrm{x}}\right.$ and PM).

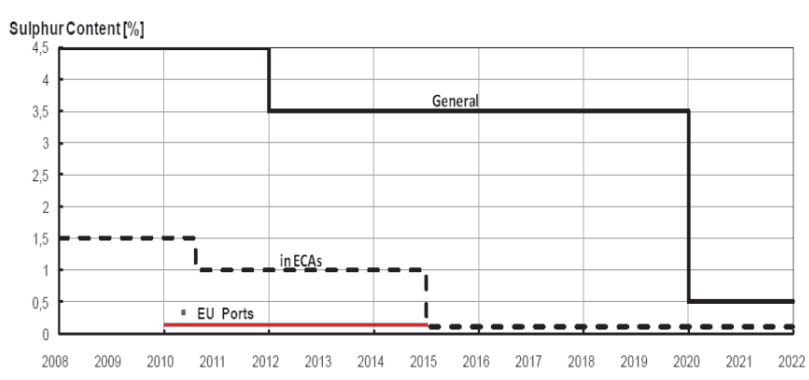

Fig. 2. Sulphur content limits in [\%] for emissions regulations dedicated to water means of transport in the period 2008-2022 [4-5]

Rys. 2. Limity zawartości siarki w paliwie wyrażone w [\%] dla norm emisji środków transportu wodnego dla okresu 2008-2022 [4-5]

Most ships which operate both outside and inside these ECAs have to operate on different fuel oils in order to comply with the respective limits. In such cases, prior to entry into the ECA, it is required to have fully changed-over to using the ECA compliant fuel oil and to have onboard implemented written procedures as to how this is to be undertaken. Similarly change-over from using the ECA compliant fuel oil is not to commence until after exiting the ECA. At each change-over it is most required that the quantities of the ECA compliant fuel oils onboard are recorded, together with the date, time and position of the ship when either completing the change-over prior to entry or commencing change-over after exit from such areas.

\section{Research method}

Fuel being brought to engine cylinders contains potential and chemical energy, which is changed by a combustion process into thermal energy. The velocity of a flame propagation and speed of combustion reactions influence on the run of combustion process taking place in a compression-ignition engine and decide about the intensity of a heat release and the reaction time. Chemical conversions of a fuel-air mixture in a compression-ignition engine belong to a continuous process. Although it is, it can be singled out three characteristic combustion periods: I - initial period until first signs of the reaction take place, $\mathrm{II}$ - period of reaction development in all space of the combustion chamber, III - finish period of the fuel burning in the volume filled with the flame. The quality of an injection process, air whirling in a combustion chamber and the composition of the combustion mixture and gases that change constantly influence on the quality and runs of the processes in each of the mentioned periods. Ignition in compression-ignition engines is qualified with the obtaining of some critical reaction speed, in which the stream of the heat release assures the flame comes out. The necessary condition for this process is to assure the collision of reagent molecules or atoms. Frequency of collisions is proportional to the concentration of molecules or atoms (depends on a temperature and an activation energy). This terminal energy
W wyniku wejścia w życie w dniu 1.01.2012 zweryfikowanej wersji Aneksu VI konwencji MARPOL, całkowita zawartość siarki w paliwie została zredukowana z 4,5 do 3,5 \%. Przewiduje się, że od 1.01.2020 zawartość siarki w paliwie będzie obniżona do maksymalnie $0,5 \%$, a studium wykonalności tego założenia ma być zakończone najpóźniej do 2018 roku. Limity $\mathrm{SO}_{\mathrm{x}}$ i cząstek stałych, obowiązujące na obszarach ECA, zostały z dniem 1.07.2010 obniżone z $1,50 \%$ do $1,00 \%$ i będą następnie dalej ograniczone do $0,1 \%$ z dniem 1.01.2015 (rys. 2).

Ustanowione obszary ECA to:

1. Morze Bałtyckie - zdefiniowany w Aneksie I konwencji MARPOL, dotyczy wyłączenie $\mathrm{SO}_{x}$,

2. Morze Północne - zdefiniowany w Aneksie V konwencji MARPOL, dotyczy wyłączenie $\mathrm{SO}_{\mathrm{x}}$,

3. Obszar Ameryki Północnej - zdefiniowany w dodatku VI do Aneksu VI konwencji MARPOL ( $\mathrm{SO}_{\mathrm{x}}, \mathrm{NO}_{\mathrm{x}}$ i PM),

4. Obszar Morza Karaibskiego należący do Stanów Zjednoczonych Ameryki, który ma wejść w życie 1.01.2014 - zdefiniowany w dodatku VI do Aneksu VI konwencji MARPOL ( $\mathrm{SO}_{x}, \mathrm{NO}_{x}$ i PM).

Większość statków, które pływają zarówno poza jak i w obszarach ECA, aby spełnić określone przepisami wymagania, jest zmuszona do pracy z wykorzystaniem różnych paliw. W takich przypadkach jeszcze przed wpłynięciem statku w strefę obszaru ECA konieczne jest całkowite przełączenie instalacji paliwowej silnika na paliwo o odpowiedniej zawartości siarki. Dodatkowo każdy statek zobowiązany jest do stosowania odpowiednich procedur rejestracji zmian zastosowanego paliwa. Podobnie podczas opuszczania strefy ECA zmiana zasilania odpowiednim paliwem nie może nastąpić przed przekroczeniem granicy tej strefy. Przy każdej zmianie rodzaju paliwa, zarówno podczas wpływania jak i wypływania ze strefy ECA, kluczową kwestią jest odnotowanie ilości paliwa o niskiej zawartości siarki w zbiornikach, włącznie z datą, godziną i pozycją statku.

\section{Metoda badawcza}

Paliwo dostarczane do cylindrów silnika spalinowego zawiera energię potencjalną i chemiczną, która jest zamieniana $\mathrm{w}$ energię cieplną w procesie spalania. Prędkość rozprzestrzeniania się płomienia i szybkość reakcji spalania wpływają na przebieg procesu spalania w silniku o zapłonie samoczynnym oraz decydują o ilości wydzielanego ciepła i czasie reakcji. Przemiany chemiczne mieszanki paliwowo-powietrznej w silniku ZS są procesem ciągłym. Mimo iż tak jest, można wyróżnić w nim trzy charakterystyczne okresy spalania: I - okres początkowy do chwili powstania pierwszych oznak rozpoczęcia reakcji, II - okres rozwoju reakcji w całej przestrzeni komory spalania, III - okres końcowy spalania paliwa w objętości zajętej przez płomień. Jakość wtrysku paliwa, zawirowania powietrza w komorze spalania i składu mieszanki spalania i spalin, które ciągle ulegają zmianie, wpływają na jakość przebiegów procesów w każdym z rozważanych okresów. Zapłon w silnikach ZS jest uzależniony uzyskaniem określonej granicznej prędkości reakcji, przy której strumień wydzielanego ciepła zapewnia powstanie płomienia. Warunkiem koniecznym do zaistnie- 
allows a molecule to enter reactions. According to physical and chemical combustion theory there are high-temperature and low-temperature ignitions in compression-ignition engines. When the proper run of the above processes is assured the combustion process occurs and its run is correct. All disruptions in this process cause that some irregularities appear during a production of chemical combustion reactions, what can cause the lack of a combustion or its run with products of an incomplete and deficient combustion. The lack of ignition results in a loss of all chemical energy contained in the injected fuel, which decreases of overall engine effectiveness and hydrocarbon and particulate matter emission increase.

Authors of a paper chosen main processes to assess complex energy changes taking place in internal combustion engines during generation and run of such dynamic process in their work cycles. In order to describe changes in such technical objects during combustion process run, values of a pressure in a cylinder in different working cycles were considered. Correctness of combustion process in engine cylinders were taken into account in the point of view of onboard diagnostics system realization. It is needed to look for new methods that will allow to diagnose combustion engines work in operation conditions and in different engine technical states. That is why authors considered the possibility of use the vibroacoustics processes in such strategy to engines of water means of transport because they still are sources of a drive that are not enough controlled and assessed with the diagnostics theory principles.

The research of the main and accompanying processes in internal combustion engines of water means of transport through vibroacoustics methods has been performed based on the active experiment, meaning a deliberate modification of input parameters and observation of their impact on output parameters. Research was performed at the engine test stand, and working conditions reflected different engine speed and torque. The test measuring points were located on the engine cylinder head. The points were selected according to the principle that the sensor should be placed closest to the point where the tested process-related vibration signal is generated.

Whole recorded signal was divided into signal sequences including single working cycles of the internal combustion engine. Divided measurement signals allowed to consider the influence of the single combustion process on the chosen vibration and acoustic signals parameters and, in consequence, calculate differences of these parameters for the proper combustion process and cycles, in which misfire events occurred. The quantitive analysis of the vibration signal has been performed through dimensional and non-dimensional point measures of such accompanying processes.

The combinations of different methods of a signal selection, apart from basic methods of a vibration analysis, were used during the research. The dynamics of diagnostic symptoms describing combustion process negative changes was increased. The task of time-spectral selection procedures was to get out and/or display pieces of information connected nia powyższego procesu jest zapewnienie zderzeń między molekułami lub atomami reagentów. Częstotliwość zderzeń jest proporcjonalna do stężenia molekuł lub atomów (zależy od temperatury i energii aktywacji). Powyższa graniczna wartość energii umożliwia molekule rozpoczęcie reakcji. Zgodnie z fizyczną i chemiczną teorią spalania w silnikach ZS występują wysoko- i niskotemperaturowe zapłony. Jeżeli zapewni się właściwy przebieg powyższych procesów, wówczas nastąpi proces spalania, a jego przebieg jest prawidłowy. Wszelkie zakłócenia w tym procesie powodują wystąpienie pewnych nieregularności w rozwoju reakcji chemicznych, które mogą skutkować nie wystąpieniem spalania lub jego przebiegiem z tworzeniem produktów niezupełnego i niecałkowitego spalania. Brak zapłonu powoduje utratę całej energii chemicznej zawartej w dawce wtryśniętego paliwa, wpływając na obniżenie sprawności ogólnej silnika oraz wzrost emisji węglowodorów i cząstek stałych.

Autorzy pracy wybrali procesy główne do oceny zmian energii całkowitej w silnikach spalinowych podczas generacji i przebiegu powyższych procesów dynamicznych w ich cyklach roboczych. W celu opisu zmian zachodzących w powyższych obiektach technicznych podczas przebiegu procesu spalania, uwzględniono wartości ciśnienia w cylindrze w różnych cyklach roboczych. Rozważano poprawność przebiegu procesu spalania w cylindrach z punktu widzenia realizacji systemu diagnostyki pokładowej. Niezbędne jest poszukiwanie nowych metod, dzięki którym możliwe będzie diagnozowanie pracy silników spalinowych w różnych warunkach ich pracy i stanu technicznego. Z tego względu autorzy rozważyli możliwość zastosowania procesów wibroakustycznych w powyższej strategii do silników stosowanych w wodnych środkach transportu, z uwagi na to, że nadal stanowią źródła napędu niewystarczająco kontrolowane i analizowane $\mathrm{z}$ uwzględnieniem zasad teorii diagnostyki.

Badania procesów głównych i towarzyszących zachodzących w silnikach spalinowych środków transportu wodnego z zastosowaniem metod wibroakustycznych przeprowadzono, bazując na eksperymencie czynnym, polegającym na świadomej modyfikacji parametrów wejściowych i obserwacji ich wpływu na parametry wyjściowe. Badania przeprowadzono w warunkach hamowni silnikowej, w warunkach zmiennej prędkości obrotowej i momentu obrotowego silnika.

Punkty pomiarowe zlokalizowano na głowicy silnika. Wybrano je zgodnie z zasada, iż przetwornik pomiarowy musi być umiejscowiony najbliżej punktu generacji sygnału drganiowego skorelowanego z ocenianym procesem.

Cały zapisany sygnał podzielono na sekwencje odpowiadające pojedynczym cyklom pracy silnika. Podzielone sygnały pomiarowe umożliwiły rozważenie wpływu pojedynczego procesu spalania na wybrane parametry sygnału drganiowego i akustycznego i, w konsekwencji, określenie różnic niniejszych parametrów dla prawidłowego procesu spalania i cykli, w których nie było zapłonu. Analizę ilościową sygnału drganiowego przeprowadzono uwzględniając wymiarowe i bezwymiarowe miary punktowe powyższych procesów resztkowych. 
with the combustion process in an engine cylinder from the vibration process. Apart from vibration transducers, the tachometric transducer was used in the phenomenon area to identify cycle phases during engine work.

Ignition and a further development of the combustion process results in an abrupt surge of the amplitude of the vibration acceleration in measuring signals. The values of the amplitudes of the vibration acceleration signals in the cycles are directly connected to the change in the peak value of the cylinder pressure in these cycles. In the case of a misfire, the surge of the amplitude of the vibration signals does not occur.

\section{Measurement test bench and work conditions}

The authors performed the specified research of combustion process in the point of view of the on-line diagnosis of the such process and its lack. The paper considers the phase of the research, which was conducted on a test bench in stationary conditions for SULZER type 6 AL 20/24 engine (Fig. 3, Table 3).

Table 3. The features of the engine used in the research

Tabela 3. Dane techniczne silnika zastosowanego w badaniach

\begin{tabular}{|l|c|}
\hline \multicolumn{1}{|c|}{ Parameter/parametr } & Value/wartość \\
\hline Type/rodzaj & In-line, CI engine \\
\hline Number of cylinders/liczba cylindrów & 6 \\
\hline Type of charging system/rodzaj doładowania & Turbocharger \\
\hline $\begin{array}{l}\text { Cylinder diameter/piston stroke /średnica cylin- } \\
\text { dra/skok tłoka [mm] }\end{array}$ & $200 / 240$ \\
\hline $\begin{array}{l}\text { Engine displacement/1 cylinder/objętość skokowa } \\
\text { cylindra [cm }{ }^{3} \text { ] }\end{array}$ & 7540 \\
\hline \begin{tabular}{l} 
Compression ratio/stopień sprężania $[-]$ \\
\hline Mean piston speed/średnia prędkość tłoka $[\mathrm{m} / \mathrm{s}]$
\end{tabular} & $12.7: 1$ \\
\hline $\begin{array}{l}\text { Maximum effective power [kW/1 cyl.] for } \mathrm{n}= \\
750 \text { rpm/znamionowa moc użyteczna [kW/1 cyl.] } \\
\text { dla } n=750 \text { obr/min }\end{array}$ & 6 \\
\hline $\begin{array}{l}\text { Mean effective pressure/średnie ciśnienie uży- } \\
\text { teczne [MPa] }\end{array}$ & 1.52 \\
\hline $\begin{array}{l}\text { Fuel injection pressure/ciśnienie wtrysku paliwa } \\
{[\mathrm{MPa}]}\end{array}$ & 24.5 \\
\hline Combustion pressure/ciśnienie spalania $[\mathrm{MPa}]$ & $10.5-11$ \\
\hline
\end{tabular}

Measurements signals obtained from microphones and transducers (Fig. 4, Table 4-5) were delivered to amplifiers, in which were amplified and normalized. They were delivered to analog inputs of the data acquisition card then. Measurements signals were filtered inside the card with the help of analog and digital filters, after which were processed from the analog to digital form. Signals obtained in the data acquisition card, in the digital form, were recorded in a computer memory. Recorded all time history runs of the measurement signals were taken to the time selection process. In the above selection all recorded signal was divided into signal sequences including single working cycles of the internal combustion engine. Divided measurement signals allowed authors of the paper to consider the influence of the single combustion process on the chosen vibroacoustic
W ramach badań połączono różne metody selekcji sygnału, wraz podstawowymi metodami analizy drganiowej. Dynamika zmian symptomów diagnostycznych opisujących nieprawidłowości zachodzące podczas spalania była wysoka. Zadaniem procedur selekcji czasowo-częstotliwościowej było uzyskanie i przedstawienie informacji odzwierciedlających proces spalania $\mathrm{w}$ cylindrze silnika w procesie drganiowym. Poza przetwornikami drgań, w badaniach zastosowano znacznik kąta obrotu wału korbowego, celem identyfikacji faz cyklu roboczego podczas pracy silnika.

Zapłon i dalszy rozwój procesu spalania powoduje gwałtowny wzrost amplitudy przyspieszeń drgań w mierzonych sygnałach. Wartości amplitud przyspieszeń drgań w cyklach są ściśle związane ze zmianami wartości szczytowej ciśnienia w cylindrze dla niniejszych cykli. Brak zapłonu powoduje brak powyższego wzrostu w sygnałach drganiowych.

\section{Stanowisko pomiarowe i warunki pracy}

W ramach pracy autorzy przeprowadzili określone badania procesu spalania w kontekście ciągłej diagnostyki niniejszego procesu i wykrycia jego braku. W pracy rozważono badania przeprowadzone na hamowni silnikowej w warunkach stacjonarnych na silniku SULZER, typ 6AL 20/24 (rys. 3, tabela 3).
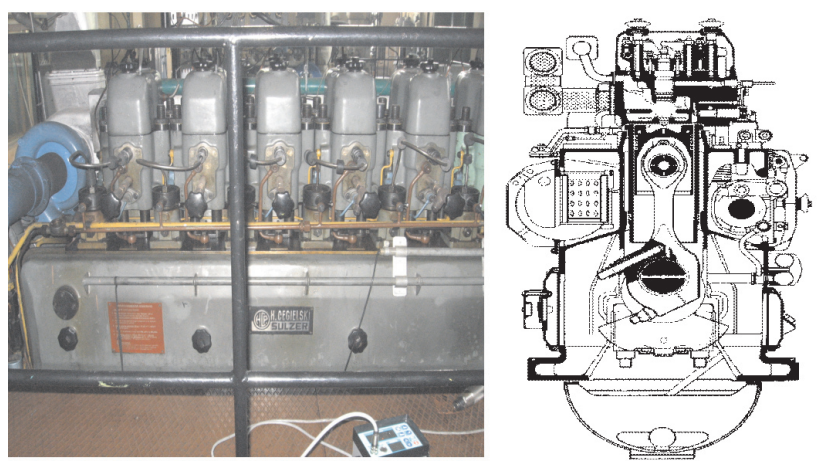

Fig. 3. The view and a cross-section of a SULZER 6AL 20/24 engine Rys. 3. Widok i przekrój poprzeczny silnika SULZER 6AL 20/24

Sygnały pomiarowe uzyskane z mikrofonów akustycznych i przetworników drgań (rys. 4, tabela 4-5) były kierowane do wzmacniaczy, gdzie ulegały wzmocnieniu i normowaniu. Następnie tak uzyskane sygnały kierowano na wejścia analogowe karty do dynamicznej akwizycji danych. Wewnątrz karty pomiarowej sygnały były filtrowane $\mathrm{z}$ zastosowaniem filtrów analogowych i cyfrowych, po czym w postaci cyfrowej były zapisywane w pamięci komputera. Zarejestrowane przebiegi czasowe sygnałów pomiarowych poddano procesowi selekcji czasowej, w którym każdy z nich podzielono na sekwencje sygnałów zawierające pojedyncze cykle pracy silnika spalinowego. Podzielone sygnały umożliwiły autorom pracy ocenę wpływu pojedynczego procesu spalania na wybrane parametry sygnału wibroakustycznego i, w wyniku tego, obliczenie różnic dla procesu spalania i cykli z wypadaniem zapłonu. 
signal parameters and, in consequence, calculate differences of these parameters for the proper combustion process and cycles, in which misfire events occurred.

Measurements were performed for different engine speed and torque values, according to the following characteristics:

a) $y_{1}=f\left(N_{e}\right)$ - screw-propeller characteristic;

b) $y_{2}=f\left(n, M_{o}=\right.$ const $)-$ speed characteristic for constant torque value,

c) $\mathrm{y}_{3}=\mathrm{f}\left(\mathrm{M}_{\mathrm{o}}, \mathrm{n}=\right.$ const $)-$ load characteristic.

The following diagnostic parameters were taken into account in the research assessment:

a) parameters of main processes: injection pressure $\left(\mathrm{p}_{\mathrm{inj}}\right)$ and cylinder pressure $\left(\mathrm{p}_{\mathrm{c}}\right)$, fuel consumption $\left(\mathrm{G}_{\mathrm{e}}, \mathrm{g}_{\mathrm{e}}\right)$, efficiency $(\eta)$,

b) accompanying processes parameters: acoustic pressure level $\left(\mathrm{L}_{\mathrm{p}}\right)$, vibration accelerations in the $\mathrm{Z}$ direction for each cylinder head.

Cylinder pressure, injection pressure, acoustics pressures levels and vibration accelerations in each cylinder and other engines parameters were measured continuously and in a parallel way. A constant coolant temperature was obtained and held in each of engine stationary working points. Vibration accelerations were recorded in a $\mathrm{Z}$ direction, the parallel direction to a cylinder axis (direction of the piston movement in a cylinder). Number of the recorded engines cycles was chosen to assure the accuracy of the further statistical analyses. The numbers and ranges of the engine velocity and torque were chosen from the exploitation useful parameters of this type:

Table 4. Technical data of vibration transducers used in the research [8]

Tabela 4. Dane techniczne przetworników drgań zastosowanych w badaniach [8]

\begin{tabular}{|c|c|c|}
\hline Sensor/przetwornik & B\&K 4384 & B\&K 4391 \\
\hline Frequency/częstotliwość [Hz] & $0.1-12600$ & $0.1-12000$ \\
\hline Sensitivity/czułość $[\mathrm{pC} / \mathrm{g}]$ & 10 & 10 \\
\hline Temperature/temperatura $\left[{ }^{\circ} \mathrm{C}\right]$ & $-74-250$ & $-60-180$ \\
\hline $\begin{array}{l}\text { Residual Noise Level in Spec Freq. } \\
\text { Range (rms)/szczatkowy poziom szumu } \\
\text { dla określonego zakresu częstotliwości } \\
\text { (rms) [mg] }\end{array}$ & \pm 0.24 & \pm 0.23 \\
\hline $\begin{array}{l}\text { Maximum operational level (peak)/max } \\
\text { poziom użyteczny (szczytowy) [g] }\end{array}$ & 6000 & 2000 \\
\hline $\begin{array}{l}\text { Maximum shock level }( \pm \text { peak }) / \max \\
\text { poziom udarowy }( \pm \text { szczytowy })[\mathrm{g}]\end{array}$ & 20000 & 2000 \\
\hline Weight/masa $[\mathrm{g}]$ & 11 & 16 \\
\hline Output/rodzaj wyjścia & $\begin{array}{c}\text { Charge-PE/ } \\
\text { tadunkowe- } \\
\text { PE }\end{array}$ & $\begin{array}{c}\text { Charge-PE/ } \\
\text { tadunkowe- } \\
\text { PE }\end{array}$ \\
\hline $\begin{array}{l}\text { Unigain/Triaxial/TEDS/Unigain/Trój- } \\
\text { osiowy/TEDS }\end{array}$ & Yes/No/No & $\mathrm{Yes} / \mathrm{No} / \mathrm{No}$ \\
\hline $\begin{array}{l}\text { Resonance frequency/częstotliwość } \\
\text { rezonansowa }[\mathrm{Hz}]\end{array}$ & 42000 & 40000 \\
\hline
\end{tabular}

a)

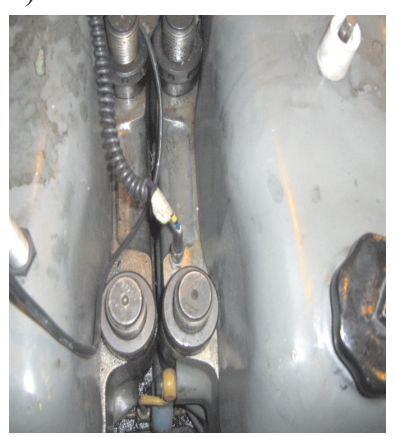

b)

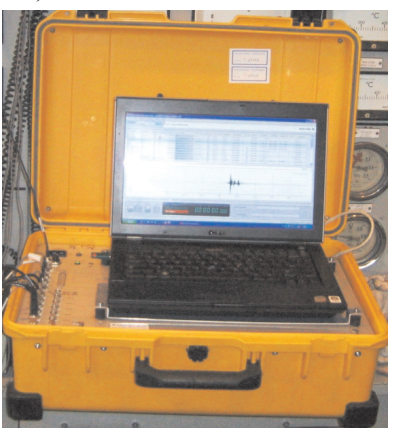

Fig. 4. Placement of a vibration transducers on the engine (a) and the view of a B\&K PULSE 3560 measurement set (b)

Rys. 4. Rozmieszczenie przetworników drgan na silniku (a) oraz widok systemu pomiarowego B\&K PULSE 3560 (b)

Pomiary przeprowadzono dla różnych wartości prędkości obrotowej i momentu obrotowego, zgodnie z następującymi charakterystykami:

a) $\mathrm{y}_{1}=\mathrm{f}\left(\mathrm{N}_{\mathrm{e}}\right)$ - charakterystyka śrubowa;

b) $y_{2}=f\left(n, M_{o}=\right.$ const $)$ - charakterystyka prędkościowa dla stałej wartości momentu obrotowego,

c) $\mathrm{y}_{3}=\mathrm{f}\left(\mathrm{M}_{\mathrm{o}}, \mathrm{n}=\mathrm{const}\right)$ - charakterystyka obciążeniowa.

$\mathrm{W}$ analizie pomiarowej brano pod uwagę następujące parametry diagnostyczne:

a) parametry procesów roboczych: ciśnienie wtrysku paliwa $\left(\mathrm{p}_{\text {inj }}\right)$ i ciśnienie w cylindrze $\left(\mathrm{p}_{\mathrm{c}}\right)$, zużycie paliwa $\left(\mathrm{G}_{\mathrm{e}}, \mathrm{g}_{\mathrm{e}}\right)$, sprawność ( $)$,

b) parametry procesów towarzyszących: poziom ciśnienia akustycznego $\left(\mathrm{L}_{\mathrm{p}}\right)$, przyspieszenia drgań w kierunku $\mathrm{Z}$ na głowicy każdego z cylindrów.

Table 5. Technical data of the acoustic B\&K 4189 A-021 microphones used in the noise research [8]

Tabela 5. Dane techniczne B\&K 4189 A-021 zastosowanych $w$ badaniach hałasu [8]

\begin{tabular}{|c|c|}
\hline Sensor, feature/przetwornik, cecha & B\&K 4189 A-021 \\
\hline Transducer type/rodzaj przetwornika & 4189 \\
\hline Preamplifier type/rodzaj przedwzmacniacza & 2671 \\
\hline Equipment complying/zgodność sprzętowa & IEC 61672 class 1 \\
\hline Diameter/średnica [cal] & $1 / 2$ \\
\hline Dynamic range/zakres dynamiczny [dB] & $16.5-134$ \\
\hline Frequency range/zakres częstotliwości $[\mathrm{Hz}]$ & $20-20000$ \\
\hline $\begin{array}{l}\text { Inherent noise/poziom szumu wewnętrznego } \\
\text { [dBA] }\end{array}$ & 16.5 \\
\hline $\begin{array}{l}\text { Lower limiting freq. }-3 \mathrm{~dB} / \text { mniejsza częstotli- } \\
\text { wość graniczna }-3 \mathrm{~dB}[\mathrm{~Hz}]\end{array}$ & 20 \\
\hline $\begin{array}{l}\text { Pressure coefficient/wspótczynnik ciśnienia } \\
{[\mathrm{dB} / \mathrm{kPa}]}\end{array}$ & -0.01 \\
\hline Sensitivity/czułość $[\mathrm{mV} / \mathrm{Pa}]$ & 50 \\
\hline Standards/standardy & $\begin{array}{l}\text { IEC 61094-4 } \\
\text { WS2F }\end{array}$ \\
\hline $\begin{array}{l}\text { Temperature coefficient/wspótczynnik tempera- } \\
\text { tury }\left[\mathrm{dB} /{ }^{\circ} \mathrm{C}\right]\end{array}$ & -0.006 \\
\hline Temperature range/zakres temperatury $\left[{ }^{\circ} \mathrm{C}\right]$ & $-30-100$ \\
\hline Input type/rodzaj wejścia & CCLD IEPE \\
\hline
\end{tabular}


a) engine speed values $n$ [rpm]: 400 (idle run), 450, 500, $550,600,650,700,750$;

b) engine effective power values $\mathrm{N}_{\mathrm{e}} / \mathrm{N}_{\mathrm{e} \text {, nominal }}$ [\%]: $0.1,0.25$, $0.5,0.75,1.0$

c) maximum torque for full effective power characteristic $\left(\mathrm{n} / \mathrm{n}_{\text {nominal }}=0.53,0.6,0.67,0.73,0.8,0.87,0.93,1.0\right)$.

\section{Digital signal post-processing algorithm}

Obtained research results and dependences between processes parameters allow to build assessment algorithm of correctness of the combustion process run taking place in an internal combustion engine with the use of the main and accompanying processes. Such algorithm is based on the use of: cylinder pressure, injection pressure, vibration and acoustic signals parameters obtained from the vibration acceleration sensor, which gives the output signal of the engine head vibration about the combustion process. Domain of an analysis contains time-domain signal runs, amplitude points measures and frequency domain assessment. Because of that it is possible to define precisely incorrect combustion processes and to assess quantity changes taking place in them (Fig. 5).

\section{Conclusions}

The presented article is the first part of the scientific and research work of the authors. It contains the most important part of the research process in the point of view of the proper measurement process: methodology and all pieces of information on how it was done and why. In this aspect there is a lot of information about the aims of this work, its potential application, about a method used by authors to assess a good scientific results applicable in means of transport solutions. Then the measurement method and systems were described, the research object and measurements conditions particularly. Assessment of the signal recording direction and transducers placement on the engine, frequency band range and a choice of a method of recording were considered in the previous works of authors. The next paper will contain measurements results and analyses,
Ciśnienie w cylindrze, ciśnienie wtrysku paliwa, poziomy ciśnienia akustycznego i przyspieszenia drgań dla każdego z cylindrów i pozostałe parametry silnika mierzono w sposób ciągły i równolegle. Utrzymywano stałą wartość temperatury cieczy chłodzącej w każdym ze stacjonarnych punktów pracy silnika. Przyspieszenia drgań rejestrowano w kierunku Z, równoległym do osi cylindra (kierunek poruszania się tłoka w cylindrze). Liczbę rejestrowanych cykli roboczych silnika dobrano wg zasady zapewnienia dokładności dalszych analiz statystycznych. Liczby i zakresy prędkości i obciążenia silnika wybrano z obszaru użytecznego parametrów eksploatacyjnych:

a) wartości prędkości obrotowej silnika [obr/min]: 400 (bieg jałowy), 450, 500, 550, 600, 650, 700, 750;

b) wartości mocy użytecznej $\mathrm{N}_{\mathrm{e}} / \mathrm{N}_{\mathrm{e} \text {, nominal }}[\%]: 0,1 ; 0,25 ; 0,5$; 0,$75 ; 1,0$

c) maksymalny moment obrotowy dla charakterystyki pełnej mocy $\left(\mathrm{n} / \mathrm{n}_{\text {nominal }}=0,53 ; 0,6 ; 0,67 ; 0,73 ; 0,8 ; 0,87\right.$; $0,93 ; 1,0)$.

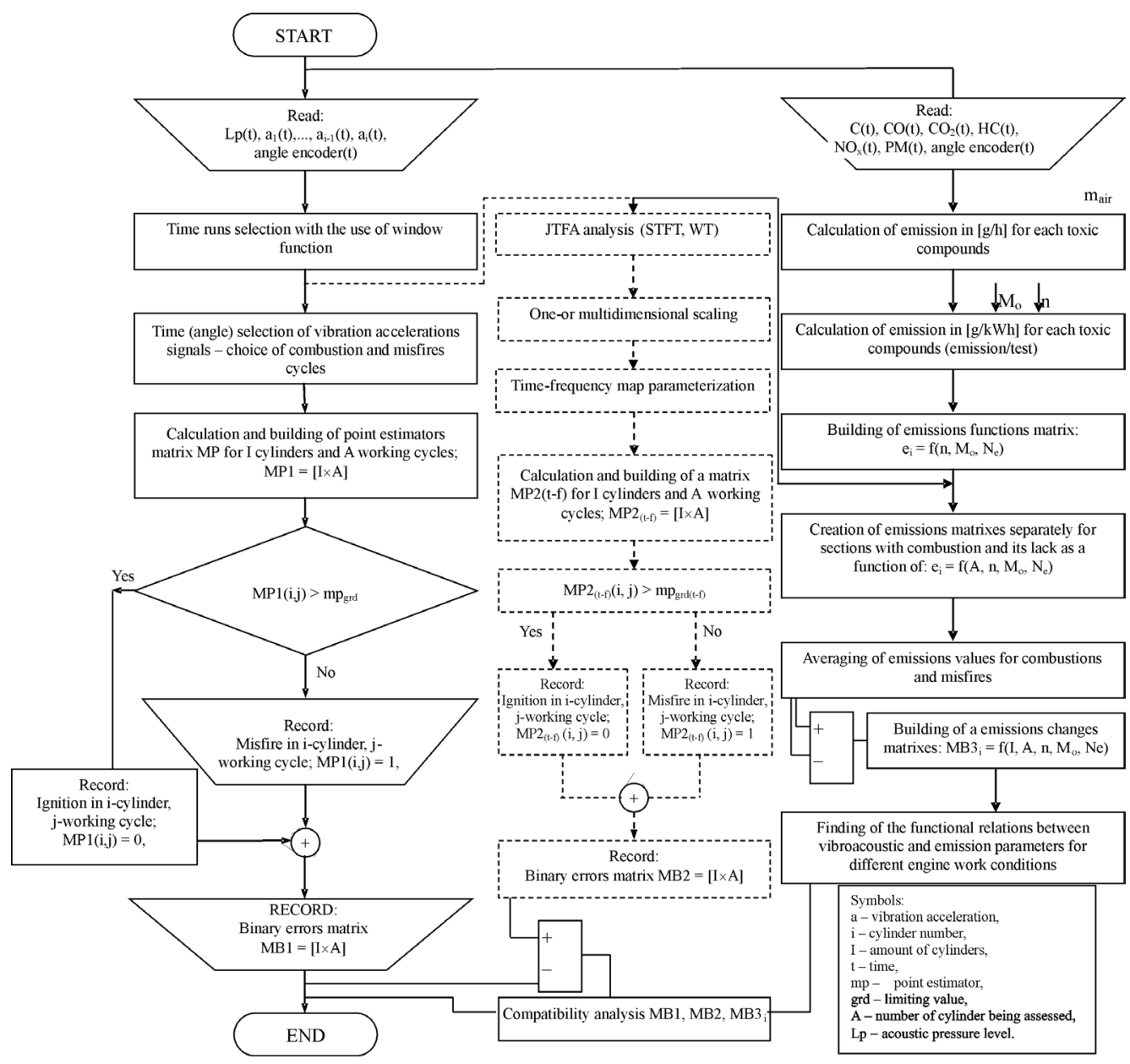

Fig. 5. Algorithm of a combustion process run correctness basing on main and accompanying processes estimators Rys. 5. Algorytm oceny poprawności przebiegu procesu spalania oparty na estymatorach procesów głównych $i$ towarzyszacych

\section{Algorytm analizy sygnału cyfrowego}

Uzyskane wyniki badań i zależności miedzy parametrami procesów umożliwiają zbudowanie algorytmu oceny po- 
also with the assumption of the diagnostic parameters (dimensional and non-dimensional estimators of the dynamic process) and special conditions of the diagnostic process performed with a vibroacoustic signal tools. Accuracy of the method will be considered and detailed conditions of the algorithm building for application purpose as well.

The combustion engines can be sources of many signals which are good for analysis - it is enough to mention vibration signals form sensors attached into engine, all acoustic signals, signals form the ionic currents detectors, signals representing crankshaft angle speed, pressure signals, and even visual signals which can show e.g. the engine head heating. The combustion engine shows, so called, cyclic variability of energy release form one cycle to another. In literature the cyclic variability is described in stochastic, linear deterministic or chaotic deterministic way, and all the time one can find the discourse on the real nature of cyclic variability.

Measurements results pointed that the vibration signal can be used to the on-line assessment of the misfire events which occur during normal working of an internal combustion engine. The ignition causes the impulse changes of the vibration signal amplitudes and the combustion process has its representation at this signal. It is distinct in each working cycle independently from the cylinder number, what confirms the reliability of the method in relation to use a method in analyses of processes taking place in multi-cylinder compression-ignition engines.

A continuous process of engine deterioration, being intensified by improper operation, leads directly to a deterioration of the performance quality, imprecision in mixture formation, distortion in the combustion process, drop in engine durability and, consequently, to its ultimate failure. Each of the above factors has the impact on the engine exhaust emissions, which is vital for the environment protection and human health. That is one of the main reasons why the diagnostics of a unit in its whole period of operation becomes increasingly important.

Such diagnosis gives precise pieces of information on correctness of the process and its lack, what makes diagnostics more reliable. Deterioration of the engine exploitation characteristics and subassemblies malfunctions influence on the emissions increase above their limits. The proper diagnosis assures to find malfunctions and their sources during normal ships operation and eliminate them. In the result, water means of transport equipped with combustion engines can be covered by on-line diagnosis, what will influence on improvement of their ecological characteristics. The described method concerns the combustion process diagnosis, so it might be helpful for the on-line control of that process for a better EOBD (European On-Board Diagnostics) strategy.

\section{Nomenclature/Skróty i oznaczenia}

$\mathrm{CO}$ carbon oxide/tlenek węgla

$\mathrm{CO}_{2}$ carbon dioxide/dwutlenek wegla

ECA Emission Control Areas/obszary kontroli emisji

EOBD European On-Board Diagnostics/europejski system diagnostyki poktadowej prawności przebiegu procesu spalania w silniku spalinowym wykorzystującego procesy robocze i resztkowe. Algorytm taki jest oparty na wykorzystaniu: ciśnienia w cylindrze, ciśnienia wtrysku paliwa, parametrów sygnału drganiowego i akustycznego, uzyskanych z przetwornika przyspieszeń drgań, dzięki któremu otrzymuje się sygnał wyjściowy drgań głowicy przenoszący informację o procesie spalania w silniku. Analizę przeprowadzono w dziedzinie czasu, amplitudowych wartości procesów i częstotliwości. Dzięki temu jest możliwa dokładna identyfikacja nieprawidłowości $\mathrm{w}$ procesie spalania i ilościowe określenie różnic $\mathrm{w}$ nich występujących (rys. 5).

\section{Wnioski}

Prezentowana praca stanowi pierwszą część opracowania naukowego i badawczego zrealizowanego przez jej autorów. Zawiera najważniejszą część procesu badawczego z punktu widzenia właściwej realizacji procesu pomiarowego: metodologii i informacji o celowości oraz przedmiocie badań. W tym kontekście przedstawiono szereg informacji o zasadności przeprowadzenia takich badań, jej potencjalnego wykorzystania w praktyce, zastosowanej metodzie badawczej, u podstaw której było uzyskanie dobrych naukowo wyników możliwych do zastosowania w środkach transportu. Ponadto opisano metodę i systemy pomiarowe, obiekt badań i warunki pomiarów. Ocenę kierunku rejestracji sygnałów pomiarowych i umiejscowienia przetworników drgań na silniku, zakres pasma częstotliwości i wybór metody rejestracji przeprowadzono we wcześniejszych pracach autorów. W następnych pracach zostaną przedstawione wyniki badań i ich analiza, ocena parametrów diagnostycznych (wymiarowych i bezwymiarowych estymatorów procesu dynamicznego) i szczegółowe warunki procesu diagnostycznego dokonanego z wykorzystaniem narzędzi wibroakustycznych. Ponadto będzie wyznaczona dokładność metody i opisane szczegółowe wytyczne dotyczące budowy algorytmu z uwzględnieniem problemów jego aplikacji.

Silniki spalinowe mogą stanowić źródła wielu sygnałów możliwych do wykorzystania w procesie analizy - wśród nich wymienić można sygnały drganiowe uzyskane z przetworników umieszczonych na silniku, wszystkie sygnały akustyczne, sygnały z detektorów prądów jonizacji, sygnały reprezentujące prędkość kątową wału korbowego silnika, sygnały ciśnienia, lub nawet sygnały optyczne, dzięki którym możliwa jest obserwacja, np. wzrostu temperatury głowicy. Silniki spalinowe charakteryzują się tzw. cykliczną zmiennością wydzielania energii w każdym z cykli roboczych. W literaturze cykliczną zmienność definiuje się w sposób stochastyczny, liniowo deterministyczny bądź w obszarze chaosu deterministycznego, w każdym czasie można znaleźć zakłócenia rzeczywistej natury zmienności cyklicznej.

Wyniki pomiarów potwierdziły, iż sygnał drganiowy może być zastosowany w ciągłej analizie zjawisk wypadania zapłonu występujących podczas normalnej pracy silnika spalinowego. Zapłon powoduje impulsowe zmiany amplitud sygnału drganiowego a proces spalania ma swoje odzwierciedlenie w tego typu sygnale, w każdym z cykli roboczych silnika, niezależnie od numeru cylindra, co potwierdza 
$\mathrm{e}_{\mathrm{ZT}} \quad$ specific emission of the toxic compound/emisja jednostkowa sktadnika spalin

$\mathrm{E}_{\mathrm{ZTi}} \quad$ mmission stream for i toxic compound/natężenie emisji dla i-tego sktadnika spalin

$\mathrm{g}_{\mathrm{e}} \quad$ specific fuel consumption/jednostkowe zużycie paliwa

$\mathrm{G}_{\mathrm{e}} \quad$ stream of a fuel consumption/natężenie zużycia paliwa

HC hydrocarbon/węglowodór

HDV Heavy Duty Vehicle/pojazdy ciężarowe o dopuszczalnej masie calkowitej powyżej $3500 \mathrm{~kg}$

IMO International Maritime Organization/Międzynarodowa Organizacja Morska

JTFA Joint Time-Frequency Analysis/analiza czasowo-częstotliwościowa

$\mathrm{L}_{\mathrm{p}} \quad$ acoustic pressure level/poziom ciśnienia akustycznego

MB binary errors matrix/binarna macierz uszkodzeń

MEPC Marine Environment Protection Committee/Morski Komitet Ochrony Środowiska

$\mathrm{M}_{\mathrm{o}} \quad$ torque/moment obrotowy

$\mathrm{n}^{\mathrm{o}}$ engine speed/prędkość obrotowa

$\mathrm{N}_{\mathrm{e}} \quad$ effective power/moc użyteczna

$\mathrm{NO}_{x}$ nitrous oxides/tlenki azotu

$\mathrm{p}_{\mathrm{c}} \quad$ cylinder pressure/ciśnienie $w$ cylindrze

$\mathrm{P}_{\mathrm{ei}} \quad$ engine power/moc silnika

$\mathrm{p}_{\text {inj }} \quad$ injection pressure/ciśnienie wtrysku

$\mathrm{PM}$ particulate matter/czątka stała

$\mathrm{S}$ route/droga

$\mathrm{SO}_{\mathrm{x}} \quad$ sulphur oxides/tlenki siarki

STFT Short-Time Fourier Transform/krótkoczasowa transformata Fouriera

WT Wigner-Ville Transform/transformata Wignera Ville'a

WZ outside conditions/warunki zewnętrzne

$\eta \quad$ efficiency/sprawność wiarygodność metody w odniesieniu do zastosowania jej $\mathrm{w}$ analizach procesów zachodzących w wielocylindrowych silnikach ZS.

Ciągły proces zużywania silnika, który potęguje niewłaściwy proces eksploatacji, prowadzi bezpośrednio do obniżenia wskaźników eksploatacyjnych, niewłaściwego tworzenia mieszanki, nieprawidłowego przebiegu spalania, obniżenia trwałości silnika i, w konsekwencji, do jego uszkodzenia. Każdy z powyższych czynników oddziałuje na emisję składników szkodliwych spalin, co jest istotne dla ochrony środowiska naturalnego i zdrowia człowieka. Powyższe zagadnienie stanowi jeden z głównych powodów, dla których diagnostyka obiektu technicznego w całym okresie jego eksploatacji nabiera większego znaczenia.

Powyższa diagnoza daje precyzyjne informacje o prawidłowości przebiegu procesu lub jego braku, co czyni diagnostykę bardziej wiarygodną. Pogorszenie się charakterystyk eksploatacyjnych silnika i uszkodzeń powstałych w jego podzespołach wpływa na wzrost emisji powyżej ich wartości granicznych. Należyta diagnoza zapewnia wykrycie niesprawności i ich źródeł podczas normalnej eksploatacji statku i ich usunięcie. W wyniku tego, środki transportu wodnego wyposażone w silniki spalinowe mogą być objęte ciągłą diagnostyką, co wpłynie na poprawę ich charakterystyk ekologicznych. Opisana metoda dotyczy diagnostyki procesu spalania, dzięki czemu może być pomocna w ciągłej kontroli niniejszego procesu dla strategii EOBD (European On-Board Diagnostics) i jej dokładniejszej realizacji.

\section{Bibliography/Literatura}

[1] Dudziak J.: Ship theory. The Sea Publishing House, Gdańsk 2008.

[2] Kniaziewicz T.: Problems of imission modelling process for toxic compounds of ships engines in the areas of city seaside agglomerations. The $7^{\text {th }}$ International Scientific Conference "Gas Engines" 2006. Scientific papers of Czestochowa University of Technology 162, Mechanics 26, Częstochowa 2006.

[3] Kulczyk J., Winter J.: Middle-land water transport. Publishing Office of Wroclaw University of Technology, Wrocław 2003.

Prof. Jerzy Merkisz, DSc., DEng. - Professor in the Faculty of Machines and Transport at Poznan University of Technology.

Prof. dr hab. inż. Jerzy Merkisz - profesor na Wydziale Maszyn Roboczych i Transportu Politechniki Poznańskiej.

e-mail: jerzy.merkisz@put.poznan.pl

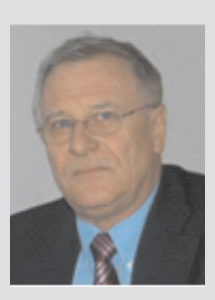

Marek Waligórski, DEng. - Doctor in the Faculty of Machines and Transport at Poznan University of Technology.

Dr inż. Marek Waligórski - adiunkt na Wydziale Maszyn Roboczych i Transportu Politechniki Poznańskiej.

e-mail:marek.waligorski@put.poznan.pl
[4] MARPOL Convention 73/78, Annex VI, IMO, London.

[5] "Meeting the next challenge. IMO Tier II and Tier III", Cummins Bulletin 2011.

[6] Michalski J.P.: Methods useful in computer needed initial design of middle-land ships. Publishing House of Gdansk University of Technology, Gdańsk 2007.

[7] “Towards IMO Tier III", MAN Diesel, 2009.

[8] www.bksv.com. (update: 22.10.2012).

Maciej Babiak, DEng. - Doctor in the Faculty of Machines and Transport at Poznan University of Technology.

Dr inż. Maciej Babiak - adiunkt na Wydziale Maszyn Roboczych i Transportu Politechniki Poznańskiej.

e-mail: maciej.babiak@put.poznan.pl

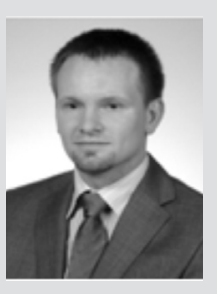

Tomasz Kniaziewicz, DEng. - Doctor in the Mechanical-Electrical Faculty at Heroes of Westerplatte Memorial Naval Academy in Gdynia.

Dr inż. Tomasz Kniaziewicz - Adiunkt na Wydziale Mechaniczno-Elektrycznym Akademii Marynarki Wojennej w Gdyni.

e-mail: tkniaziewicz@wp.pl

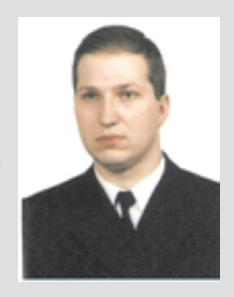

